\title{
Drug Abuse Amongst Adolescent Learners in Townships
}

\author{
Mabatho Sedibe $^{1} \cdot$ Nellie Gloria Patricia Hendricks ${ }^{1}$
}

Received: 6 June 2019 / Accepted: 20 April 2020 / Published online: 4 May 2020

(C) The Author(s) 2020

\begin{abstract}
The study explored the experiences of adolescent learners regarding drug abuse in previously disadvantaged townships in South Africa. A phenomenological research paradigm was employed, and an inductive research approach was implemented. The study followed a qualitative research design focusing on interviews and document analysis as data collection methods. Purposive sampling was done and one-on-one interviews with Life Orientation (LO) teachers in two Gauteng secondary schools were conducted as well as three Non-Governmental Organisations (NGO's) and Non-Profit Organisations (NPO's) from different organisations. Focus group interviews were conducted with adolescent learners in two Gauteng secondary schools. I further utilised an inductive content analysis using open coding and axial coding to decipher information gathered from interviews conducted with participants. The study leaned on two theoretical frameworks which include Bronfenbrenner's Nested System and Erikson's Eight Stages of Psychosocial Development. The findings indicated that adolescent learners get involved in the use of drugs due to their lack of identity formation and the need to belong. It was also discovered that adolescent learners did not master the adolescence stage successfully, hence getting involved in the use of drugs.
\end{abstract}

Keywords Adolescent learners · Adolescence $\cdot$ Drug abuse $\cdot$ Previously disadvantaged $\cdot$ Townships $\cdot$ Secondary schools

\section{Introduction and Context of the Study}

The study was conceived when parents in a previously disadvantaged township in South Africa implored the then President of the country, Mr. Jacob Zuma, to intervene in the rampant use of drugs by people residing in the township. In South

Nellie Gloria Patricia Hendricks

gloria.hendricks@gmail.com

Mabatho Sedibe

mabathos@uj.ac.za

1 University of Johannesburg, Johannesburg, South Africa 
Africa, townships refer to residential areas that are mostly occupied by Blacks and are mostly associated with poverty, crime and violence (Campbell and Meades 2007; Harber 2001; Motseke 2013; Ngonini 2007). The South African Council for Educators (SACE 2011) theorises that high levels of violence, easy access to drugs, alcohol and firearms, and high levels of crimes are found in disorganised communities that Pelser (2008) believes have been regularised by the home, school and immediate environments in which they occur. Furthermore, parents in the township posted letters in the newspapers, i.e., Sowetan (08/04/2013), The Citizen (08/04/2013), Sowetan (09/04/2013), Eldorado Urban (10/04/2013), Kwela Xpress (19/04/2013) and The Times (24/04/2013) relating their experiences with their adolescent children's widespread use of drugs and the ramifications thereof (IOL News 2013). The President heeded the call of the parents and, together with other high-ranking officials, visited the township on 14 May 2013 (IOL News 2013). The president's visit yielded results and appropriate interventions were implemented accordingly. The army was deployed to the township and police presence was evident. This prevailed for a few weeks and the use of drugs decreased in that time, however, once the army was no longer visible in the township and the police did not make their regular rounds as the president had instructed, the use and abuse of drugs continued as before. Drug abuse is defined as the inappropriate use of or addiction to drugs or intoxicating chemical substances (Grolier 1989; Van Niekerk and Wolvaardt 2011). Mandrax, crack cocaine and crystal methamphetamine (Tik) are substances often abused in South African communities (Leggett 2004). According to Wechsberg et al. (2010), the use of crystal methamphetamine is on the increase and this is particularly prevalent among young people in the Coloured communities. Children sometimes begin to take drugs at primary school and they are often persuaded by their friends to do so (Dawkins 2001; Floyd et al. 2010; Grolier 1989; Park et al. 2007). Dahl (2004) and Spear (2000) concur that drug abuse is prevalent in adolescents and Grolier (1989) notes an increase in the use of drugs amongst adolescents when they reach high school. Grolier (1989) and Webster-Stratton and Taylor (2001) state that drug abuse is most common among young people who want new sensations, an increase in their mental functioning or their ability to understand themselves. However, adolescents may also use drugs to escape negative feelings that they have about themselves (Beman 1995; Cox et al. 2007; Dawkins 2001; Joffe and Black 2012). The Oxford South African Concise Dictionary (OSACD) (2011) defines an adolescent as someone who is in the process of developing from a child to an adult. Cox et al. (2007) state that intellectual, physical and emotional development is critical during the adolescent years as it is the period when changes in biology, cognition and social and emotional development occur and there is a significant increase in emotional and behavioural difficulties (Blakemore 2008; Dahl 2004). Joffe and Black (2012) also posit that adolescence is a potentially difficult time because it is also a transitional period from primary school to secondary school and as per Erikson (1968) and Hartney (2014) this new feeling of freedom from primary school together with peer pressure may cause some learners to start experimenting with drugs as adolescent learners desire a sense of belonging to a group. Moreover, the National Education Policy Act (NEPA) 27 of 1996 similarly acknowledges that there is a mounting awareness of drug usage in schools (Brunton and Associates 
2003). According to Wechsberg et al. (2010), the use of crystal methamphetamine is on the increase and this is particularly prevalent among young people in the Coloured communities. Dahl (2004) and Spear (2000) are also of the opinion that drug abuse is prevalent in adolescents and Grolier (1989) notes an increase in the use of drugs amongst adolescents when they reach high school. Grolier (1989) and Webster-Stratton and Taylor (2001) state that drug abuse is most common among young people who want new sensations, an increase in their mental functioning or their ability to understand themselves. However, adolescents may also use drugs to escape negative feelings that they have about themselves (Beman 1995; Cox et al. 2007; Dawkins 2001; Joffe and Black 2012). Thus, this study explored the experiences of adolescent learners regarding drug abuse in previously disadvantaged townships in South Africa. Thus, this study explored the experiences of adolescent learners regarding drug abuse in previously disadvantaged townships in South Africa.

\section{Theoretical Framework}

There were two theoretical frameworks employed in this study, viz. Bronfenbrenner's Nested System (1994) and Erikson's Eight Stages of Psychosocial Development (1968). These two frameworks worked concurrently to prove the relevance of its inclusion in this study. It was hence discovered that by employing all the different levels of Bronfenbrenner's Nested System, the relationships on these different levels are vital in the forming of adolescent learners' identities and their need to belong. These different levels of system include: micro-system, meso-system, exosystem, macro-system and chrono-system (Donald et al. 2014). Furthermore, the Eight Stages of Erikson's Psychosocial Development also suggest that if adolescent learners did not master the stage of adolescence successfully, adolescent learners are bound for failure. And the opposite is noted whereby successful mastery of adolescence would ensure success for adolescent learners. Thus, adolescent learners get involved in the abuse of drugs due to failing relationships because they did not master the stage of adolescence successfully.

\section{Aim of the Study}

The aim of the study is to: "Explore, describe and interpret the experiences of adolescent learners regarding drug abuse in previously disadvantaged townships in South Africa."

\section{Research Question}

The research question is as follows: "How do adolescent learners experience drug abuse in previously disadvantaged townships in South Africa?". 


\section{Research Methods}

The study followed a Phenomenological research paradigm (Husserl 1907) because I wanted to explore the experiences of adolescent learners regarding drug abuse in previously disadvantaged townships in South Africa. Phenomenology is the study of a conscious experience and of entities' perceptions, feelings and lived experiences (Guest et al. 2013; Richards and Morse 2013). Leedy and Ormrod (2014), claim that a phenomenological study endeavours to comprehend individual's perceptions, outlooks and conceptions of a situation. In addition, Ponterotto (2005) notes that the research paradigm sets the context for any research project. Moreover, Richards and Morse (2013) claim that people are tied to their worlds and they are comprehensible only in their contexts. Richards and Morse (2013) further maintain that human behaviour occurs in the contexts of relationships to things, people, events and situations. Thus, by implementing a Phenomenological research paradigm, I was able to recognise occurrences as they are observed from those involved in the study (Groenewald 2004; Leedy 1997; Lester 1999; Richards and Morse 2013). Furthermore, the study followed an inductive approach (Mill 1898) to investigate the experiences of adolescent learners regarding drug abuse in previously disadvantaged townships in South Africa (O'Reilly and Kiyimba 2015). Leedy and Ormrod (2014) state that inductive reasoning begins with an observation and that researchers use specific events to draw conclusions about a phenomenon. Conclusions about the population are drawn from a sample being observed (Leedy and Ormrod 2014). Thus, the sample observed in this study included adolescent learners, Life Orientation (LO) teachers, Non-Governmental Organisations (NGOs) and Non-Profit Organisations (NPOs). A qualitative inductive research question was designed to explore the experiences of adolescent learners regarding drug abuse in previously disadvantaged townships in South Africa, and experiences and feelings associated with it (O'Reilly and Kiyimba 2015). Theory was established from the bottom-up rather than the top-down (Hesse-Biber and Leavy 2011; O'Reilly and Kiyimba 2015; Remler and Van Ryzin 2011). Inductive reasoning moves from specific observations to broader generalisations (O'Reilly and Kiyimba 2015; Remler and Van Ryzin 2011) and the data collected is used to generate ideas (O'Reilly and Kiyimba 2015). Furthermore, a qualitative research design was employed, because the emphasis was on the experiences of people, their behaviours and emotions (Strauss and Corbin 1999; Hesse-Biber and Leavy 2011; Guest et al. 2013). This design assisted me in finding meaning in social phenomena within natural settings with minimal disruptions (Merriam 1998; Hesse-Biber and Leavy 2011; Denzin and Lincoln 2005; Kvale 2007). Guest et al. (2013) defines qualitative research as the collecting of or working with text, images or sounds. In addition, qualitative research highlights rich descriptions in its final product (Merriam 1998). Descriptive data takes the form of words and pictures rather than numbers. They contain narratives from participants which illustrate and explain the findings (Bogdan and Bilken 1982; Guest et al. 2013; Hesse-Biber and Leavy 2011). 


\section{Sampling}

Sampling is defined as the process of selecting items from a population for inclusion into a study (Guest et al. 2013; Remler and Van Ryzin 2011; Adams et al. 2014). Thus, by employing purposive sampling, I decided the purpose that I wanted my participants to serve (Bernard et al. 2017; Daniel 2012; Remler and Van Ryzin 2011) which was to relate their experiences regarding drug abuse amongst adolescent learners in previously disadvantaged townships in South Africa. My purposeful sample (Bernard et al. 2017) consisted of 19 adolescent learners, 2 LO teachers, 3 NGOs and NPOs. Adolescent learners and LO teachers were purposefully selected from two secondary schools in a previously disadvantaged township in Gauteng. Participants were cognisant of the information required in the study and they were willing to share their knowledge (Richards and Morse 2013). Purposive sampling allowed me to illuminate features or characteristics around the subject under study, thus providing me with the information needed to answer my research question (Guest et al. 2013; Richards and Morse 2013; Ritchie and Lewis 2003), which is: "How do adolescent learners experience drug abuse in previously disadvantaged townships in South Africa?" The School Based Support Team (SBST) identified these adolescent learners whom they perceived as suitable for participation in the study due to their involvement in drug abuse. Furthermore, LO teachers in Gauteng secondary schools were included for participation in the study because they teach adolescent learners. And NGO's and NPO's were also purposefully selected due to their work amongst adolescent learners in the township regarding drug abuse. Thus, Kumar (2014) claims that participants are chosen based upon their knowledge about the topic that would be researched. Purposive sampling is useful when it pertains to describing a phenomenon (Flick 2015; Kumar 2014). Welman and Kruger (1999) and Harding (2013) concur that purposive sampling is the most important kind of non-probability sampling to locate key participants. Purposive sampling, according to Remler and Van Ryzin (2011), allows for a limited number of participants as it is an intensive and time-consuming method of data collection and analysis. Descriptions of participants are listed (Tables 1, 2 and 3).

\section{Ethical Considerations}

Researchers must act ethically as they interact with participants. Informed consent was sought from participants before the commencement of the study (Ellingson 2009; Flick 2015). They were made aware that their participation was voluntary and that they were entitled to all the details pertaining to the study they are involved in (Flick 2015; Guest et al. 2013; Remler and Van Ryzin 2011). Furthermore, participants were ensured that they would remain anonymous and the information gathered would be treated with the strictest confidentiality. They were also assured that pseudonyms would be used throughout for them not to be identified. Participants were not harmed in any way while participating in the research study (Flick 2015; Guest et al. 2013; Remler and Van Ryzin 2011). All data were gathered and protected 
Table 1 Adolescent learner participants-School 1

\begin{tabular}{|c|c|c|c|c|c|c|c|c|c|}
\hline \multirow[t]{2}{*}{ No } & \multirow[t]{2}{*}{ Pseudonyms } & \multirow[t]{2}{*}{ Grade } & \multirow[t]{2}{*}{ Age } & \multicolumn{4}{|c|}{ Living with } & \multirow[t]{2}{*}{ Siblings } & \multirow{2}{*}{$\begin{array}{l}\text { Position } \\
\text { among } \\
\text { siblings }\end{array}$} \\
\hline & & & & $\begin{array}{l}\text { Both par- } \\
\text { ents }\end{array}$ & Mother only & Father only & Other & & \\
\hline 1 & $\begin{array}{l}\text { Mark Gal- } \\
\text { lant }\end{array}$ & 9 & 14 & & & $\mathrm{X}$ & & 3 & $3 r d$ \\
\hline 2 & Deon Jones & 9 & 14 & $\mathrm{X}$ & & & & 3 & $1 \mathrm{st}$ \\
\hline 3 & $\begin{array}{l}\text { Sharon } \\
\text { Moodley }\end{array}$ & 9 & 14 & $\mathrm{X}$ & & & & 3 & 2 nd \\
\hline 4 & $\begin{array}{l}\text { Orifha } \\
\text { Maluleke }\end{array}$ & 9 & 15 & & & & $\mathrm{X}$ & 6 & 5 th \\
\hline 5 & John Oliver & 9 & 15 & $\mathrm{X}$ & & & & 3 & $2 n d$ \\
\hline 6 & $\begin{array}{l}\text { Kevin } \\
\text { Ockert }\end{array}$ & 9 & 15 & & $\mathrm{X}$ & & & 4 & 2 nd \\
\hline 7 & $\begin{array}{l}\text { Nelisiwe } \\
\text { Roberts }\end{array}$ & 9 & 14 & $\mathrm{X}$ & & & & 2 & 2 nd \\
\hline 8 & $\begin{array}{l}\text { Quentin } \\
\text { Ricketts }\end{array}$ & 9 & 16 & & & & $X$ & 4 & $1 \mathrm{st}$ \\
\hline 9 & $\begin{array}{l}\text { Zanele } \\
\text { Shongwe }\end{array}$ & 9 & 14 & $\mathrm{X}$ & & & & 1 & $1 \mathrm{st}$ \\
\hline 10 & $\begin{array}{l}\text { Amanda } \\
\text { Saunders }\end{array}$ & 9 & 15 & & & & $\mathrm{X}$ & 7 & $3 r d$ \\
\hline
\end{tabular}

ethically (Flick 2015; Guest et al. 2013). Thus, permission from the following individuals and institutions was granted before the commencement of the study:

- Ethics Committee at the University of Johannesburg

- Department of Education

- Two Gauteng secondary schools

- LO teachers

- NGO's and NPO's

- Parents of adolescent learners

- Adolescent learners

\section{Trustworthiness}

The quality of a research study can be judged by its trustworthiness and authenticity (Kumar 2014). Guba and Lincoln (1988) and Elo and Kyngäs (2007) attribute four distinctive principles to trustworthiness, viz. credibility, transferability, dependability, confirmability. Firstly, credibility was ensured by distributing transcribed interviews amongst participants in order to demonstrate that whatever transpired during the interviewing process is a true reflection, (Kumar 2014; Guba and Lincoln 1988; Morse 1994; Graneheim and Lundman 2004; 
Table 2 Adolescent learner participants-School 2

\begin{tabular}{|c|c|c|c|c|c|c|c|c|c|}
\hline \multirow[t]{2}{*}{ No } & \multirow[t]{2}{*}{ Pseudonym } & \multirow[t]{2}{*}{ Grade } & \multirow[t]{2}{*}{ Age } & \multicolumn{4}{|c|}{ Living with } & \multirow[t]{2}{*}{ Siblings } & \multirow{2}{*}{$\begin{array}{l}\text { Position } \\
\text { among } \\
\text { siblings }\end{array}$} \\
\hline & & & & $\begin{array}{l}\text { Both par- } \\
\text { ents }\end{array}$ & Mother only & Father only & Other & & \\
\hline 1 & $\begin{array}{l}\text { Beatrice } \\
\text { Bouwer }\end{array}$ & 9 & 13 & $X$ & & & & 2 & $1 \mathrm{st}$ \\
\hline 2 & $\begin{array}{l}\text { Annie } \\
\text { Human }\end{array}$ & 9 & 15 & & $X$ & & & 3 & $3 \mathrm{rd}$ \\
\hline 3 & Esther Khan & 9 & 14 & & $X$ & & & 6 & 5 th \\
\hline 4 & $\begin{array}{l}\text { Ingrid } \\
\text { Meyer }\end{array}$ & 9 & 14 & $X$ & & & & 1 & \\
\hline 5 & $\begin{array}{l}\text { Vernon } \\
\text { Peters }\end{array}$ & 9 & 14 & & & & $X$ & 4 & $1 \mathrm{st}$ \\
\hline 6 & $\begin{array}{c}\text { Marinda } \\
\text { Reid }\end{array}$ & 9 & 14 & & $X$ & & & 3 & $1 \mathrm{st}$ \\
\hline 7 & $\begin{array}{l}\text { Lorraine } \\
\text { Simons }\end{array}$ & 9 & 14 & & $X$ & & & 4 & $1 \mathrm{st}$ \\
\hline 8 & $\begin{array}{l}\text { Kaleb } \\
\text { Thomas }\end{array}$ & 9 & 15 & $X$ & & & & 2 & 2 nd \\
\hline 9 & $\begin{array}{l}\text { Maureen } \\
\text { Tose }\end{array}$ & 9 & 14 & & $\mathrm{X}$ & & & 3 & $3 \mathrm{rd}$ \\
\hline
\end{tabular}

Table 3 Adult participants

\begin{tabular}{lllll}
\hline Pseudonym & Designation & Gender & Institution Pseudonym & Job description \\
\hline Ms. Brown & Teacher & Female & Essenwood SSS & $\begin{array}{l}\text { Life Orientation Teacher and SBST } \\
\text { coordinator }\end{array}$ \\
Ms. Molefe & Teacher & Female & Mississippi SSS & $\begin{array}{l}\text { Life Orientation Teacher } \\
\text { Leon }\end{array}$ \\
Coordinator & Male & SATADA & Mentor of children referred to the centre \\
Andrew & Mentor & Male & ADRC & Mentoring children after school \\
Denise & CEO & Female & YC & Founder of YC \\
\hline
\end{tabular}

Rubin and Rubin 2005; Hesse-Biber and Leavy 2011). Secondly, transferability gave a rich description of the research study for other researchers to have a clear understanding of the study and to follow it precisely (Kumar 2014; Graneheim and Lundman 2004; Hesse-Biber and Leavy 2011). Thirdly, dependability was implemented whereby audited data transcripts was made available to other researchers to validate the authenticity of the study (Kumar 2014; Marshall and Rossman 2006). Lastly, the study was discussed with other researchers in this field to establish confirmability (Kumar 2014; Morse 1994; Marshall and Rossman 2006). 


\section{Data Collection Methods}

Data collection is a very important step in the research process (Khanzode 2011). Therefore, a process called triangulation was utilised in this study as data collection methods. Triangulation is a process whereby multiple methods are used to obtain data, thus, to confirm the findings (Flick 2014; Remler and Van Ryzin 2011; Scott and Garner 2013; Richards and Morse 2013). Triangulation also allowed me to understand my research study from two vantage points (Flick 2015). Hence, interviews and document analysis were used to collect data for this study. Furthermore, two types of interviews were conducted, and these were one-on-one interviews and focus group interviews. Two focus group interviews were conducted with adolescent learners at two secondary schools located in the previously disadvantaged township in Gauteng. Focus group 1 consisted of 10 learners and focus group 2 consisted of nine learners. These interviews were held after school and it lasted for 45 min per focus group interview. One-on-one interviews were administered with adult participants. Two LO teachers from the two schools were interviewed after school and these interviews lasted for an hour each. NGO's and NPO's interviews were conducted at the centres during office hours and these lasted for an hour as well. Furthermore, documents that were utilised for analysis included the following:

- Teacher-parent conference;

- Notice of disciplinary hearing/Urgent parental summons;

- Learner profiles;

- Learner attendance registers;

- Referral for Rehabilitation at NGO and NPO centres;

- Suspension letters; and

- Notification of learner absenteeism.

These documents were presented by the schools involved in the study to complement and corroborate the interviews conducted with adolescent learners and LO teachers. Only documents portraying problem behaviour of adolescent learners were presented to demonstrate the prevalence of problem behaviour pertaining to the abuse of drugs of adolescent learners.

\section{Data Analysis}

According to Kothari and Garg (2014), the plan for data analysis is decided beforehand. Raw data takes the form of transcriptions and/or audio recordings (Remler and Van Ryzin 2011). Data analysis comprises of organisation and interpretation of data (Remler and Van Ryzin 2011). Preparing and organising data, reducing and summarising data as well as presenting the data are all steps in the data analysis process (Remler and Van Ryzin 2011). Thus, an inductive content analysis was employed, because I did not anticipate locating data to prove or disprove theories that I had prior to the study (Bogdan and Bilken 1982; Henning et al. 2004; Harding 2013), 
but my knowledge about the topic was relatively limited, explaining the reason for choosing inductive content analysis (Elo and Kyngäs 2008; Hesse-Biber and Leavy 2011). Thus, the data was organised using open coding and axial coding. Open coding was done by writing notes and headings in the text while I read it (Elo and Kyngäs 2008; Gibbs 2007; Richards and Morse 2013; Henning et al. 2004). This was done to develop categories of information (Brown 2001; Pandit 1996). Axial coding has then allowed me to connect these categories (Brown 2001; Pandit 1996; Gibbs 2007; Richards and Morse 2013; Henning et al. 2004). Similar codes were grouped together which enabled me to develop categories and from these themes were developed (Merriam 1998; Maxwell 2008; Gillham 2000; Richards and Morse 2013). The results of the raw data then gave me the information needed to answer my research question (Wickham 2000). Hence, the following data emerged from the coded transcriptions pertaining to adolescent drug abuse, viz. contributing factors of drug abuse by adolescent learners, types of drugs consumed by adolescent learners, composition of these drugs used by adolescent learners, consumption of these drug by adolescent learners and lastly, effects of these drugs by adolescent learners, stages of drug abuse by adolescent learners.

\section{Discussion of Findings and Interpretation of Results}

\section{Contributing Factors: Peer influence}

A major contributing factor for adolescent learners to use drugs is peer influence as deduced from the findings (Rathus 2012). It was divulged in the interviews that many adolescent learners are forced by their peers to engage in the use of drugs. They may try to resist but, due to the pressures placed on them, they succumb and get involved in doing drugs. Peers also coerce adolescent learners by deceiving them into believing that there will be no repercussions when they use drugs. Adolescent learners then have no other choice but to get involved in the use of drugs. Even adolescent learners coming from good homes use drugs due to the influence of their peers. Floyd et al. (2010) support this argument that adolescent learners' peers are important sources for locating drugs. Below are verbatim responses from participants as derived from interviews conducted in exploring the experiences of adolescent learners regarding drug abuse in previously disadvantaged townships in South Africa. In Focus Group 1 lines 160-161, Orifha Maluleke* confessed to be "influenced to use ecstasy due to depression problems ... influenced by my friends". T 2 in line 23 mentioned that "they're influencing them" and $\mathrm{T} 1$ in line 55 reiterated that "others will tell you that they are influenced by the friends". T 1 in line 116 reported that the peers have "a very big influence" on the adolescent; $\mathrm{T} 1$ in line 72 also confessed that "I think it's peer pressure"; T 2 in line 221 said: "because of the peer pressure again" and NGO 2 in line 183 added that "definitely because of there are peer pressures". T 2 in line 76 commented that "they got the peer pressure is also part, is also influencing these learners in the way they behave". It is evident that peer pressure involves force, and this was noted in the interview conducted by Focus Group 1, line 59, when John Oliver* stated that "sometimes, you don't want to do it, 
and they force you to do it" and in Focus Group 2 in line 53, Kaleb Thomas* mentioned that "we become forced to do it". Adolescent learners are coerced into participating in certain activities with their friends. Orifha Maluleke* in Line 59 in Focus Group 1 stated that "they tell you, "just try this, it is not going to hurt you". Annie Human* in Focus Group 2 line 107 agreed that "their friends will tell them, "come let's do it, it's gonna feel so nice'. And, you find maybe some of the learners coming from maybe a good background, a family background, because of their friends here at school, they end up doing what their friends are doing" (line 77). Persuasion is another tactic that peers use to encourage adolescent learners to participate in certain activities. Evidence of this was found in the report from Quentin Ricketts* in Focus Group 1, line 115, maintaining that "you have this friend who says "no, come, let us go, you will do your work later'”. Also, in Focus Group 2, line 109, Vernon Peters* revealed that "they try and persuade you to do something that you really don't want to do". Orifha Maluleke* in Focus Group 1, line 60 maintained that "you say no, but they still nag you until you say, 'OK, I'll do it'”. "That friend pressures you and does not stop, until you give in, (Orifha Maluleke*, Focus Group 1, line 116). NGO 1 in line 162 alluded that "they test your ability" because "the friends want to benefit for their own personal reason" (NGO 1, line 188); "they don't worry about the next person" (NGO 1, line 190) and in Focus Group 2, line 52, Lorraine Simons* stated that "many times we just feel that we need to do this". NGO 1, line 150 believed "sometimes it's not based on the family. Experience I've seen about how ... the child turn out bad, because the child come out of a good home". NGO 1 , line 151 also mentioned that "mother and father is religious, they teach the child good manners. Other times the child is like in Grade 10, then the child just start being rebellious, but that's not something that happen in the home; it's something that happen outside. There's a lot of ways children like turn out".

\section{Academic Performance}

It was discovered from the findings that adolescent learners who abuse drugs underperform academically. These are adolescent learners who have problems with their school work. Because they cannot read and write in class, they take drugs to feel better about themselves. On the other hand, it was also discovered from the findings that not only the under-performing adolescent learners, but even high achieving adolescent learners abuse drugs due to peer pressure. Cox et al. (2007), claim that drug abuse is a precursor for poor academic performance of adolescent learners and under-performing adolescent learners are prone to use marijuana and other illicit substances. Support for these theories is found in literal responses from participants involved in the study in exploring the experiences of adolescent learners regarding drug abuse in previously disadvantaged townships in South Africa. In Focus Group 2 line 157, Lorraine Simons* responded: "it's usually the children that have problems with school work ... they end up going to substance". T 2 in line 152 mentioned that the learners "can't read and write, now they divert to this thing of smoking and using drugs". Marinda Reid* in Focus Group 2 line 160 commented that "sometimes you find those kids who are very clever at school and then they mess up 
themselves because of the peer pressure, and they start using the drugs". Thus, it can be derived from these responses that it is not only the underperforming adolescent learners, but also the high achievers who are involved in the use of drugs.

\section{Types of Drugs Adolescent Learners Abuse}

\section{Marijuana}

Marijuana is the most widely used drug in the United States of America (Pastorino and Doyle-Portillo 2009). According to Parry et al. (2004), marijuana is also the most commonly used drug in South Africa. Van Zyl (2019) claims that South Africa is the third largest producer of marijuana in the world. Also, the personal use of marijuana was decriminalised by the Constitutional Court on 18 September 2018. This ruling makes it legal for marijuana users to be in possession of marijuana or to use it in private for their own personal consumption (Constitutional Court 2018, Case CCT 108/17). Age, peers, low cost and easy accessibility of illegal drugs is related to the prevalence of drug use among adolescent learners (Parry et al. 2004). Marijuana is the drug most often used by adolescent learners (Mitterer 2011; Nevid 2013) as this study has found. Marijuana is also disguised in muffins (Nevid 2012, 2013) which are called "space-muffins". Below are verbatim responses as taken from participants interviewed in exploring the experiences of adolescent learners regarding drug abuse in previously disadvantaged townships in South Africa. NGO 2 in line 185 said: "the most used drug is actually marijuana, which is weed". NGO 3 in line 221 supported the response from NGO 2 by stating: "most of the kids that we're working with is using weed". NGO 3 in line 224 added "dagga is the most popular for the age group we are dealing with" and in line 226 emphasised that "dagga and the okka pipe" are the most popular drugs used by adolescents. Mark Gallant* in Focus Group 2, line 107 noted that "weed, or probably cigarettes that they use most of the time". In Focus Group 2, lines111-112, Vernon Peters* felt that marijuana is the most popular drugs used by adolescents and that "if you walk around, you see most of them that smokes those drugs in the bottle, they call it lollie, marijuana". T 2 in line 104 claimed that "the most thing that I know, is marijuana and the cigarette" that are mostly used by adolescent learners. Furthermore, NGO 3 in line 24 stated that adolescent learners who are brought to the centre "they are the learners who are busy experimenting with dagga".

\section{Okka Pipe}

The okka pipe is the next most used drug after marijuana. The okka pipe was considered a harmless smoking device used by adolescent learners, but it has become a popular drug in recent years. In response to the question which drugs are the most popular, Kevin Ockert* in Focus Group 1, line 218 responded: "there is also the okka pipe". In addition, NGO 1 in line 193 also said, "that is okka pipe". However, I could not obtain any evidence in literature to support this finding. 


\section{Crystal Methamphetamine}

The most commonly used amphetamines are methamphetamines which are considered to be the fastest growing drug problem in the United States of America (Pastorino and Doyle-Portillo 2009). Crystal methamphetamine, commonly known as crystal meth or tik, is also a popular drug used by adolescent learners. This theory was supported by Kaleb Thomas* in Focus Group 2 line 150 who stated that "most of the time they use crystal meth". NGO 1 in line 194 also noted that crystal meth is highly popular amongst adolescent learners: "there's crystal meth ..., in the community" and NGO 2 in line 194 added that "they will now go to crystal meth". Sharon Moodley* in Focus Group 1 line 275 commented that "sometimes the powder is formed into a tablet, that's what you call pille meth".

\section{Other Drugs Abused by Adolescent Learners}

Adolescent learners also use ecstasy, codeine, nyope, flakka, cocaine and Mandrax. In Focus group 1, line 159, Deon Jones* stated that "ecstasy is like the in-thing with the children". Mark Gallant in Focus Group 1, line 164 also mentioned that "they also use codeine". However, ecstasy and codeine were not mentioned in any of the other interviews conducted with participants. Cocaine is considered to be a dangerous stimulant drug (Pastorino and Doyle-Portillo 2009). It is said to produce states of pleasure in the user's brain (Flagel et al. 2011). Regular use can damage the heart and other organs in the body (Nevid 2013; Pastorino and Doyle-Portillo 2009) and prolonged use can lead to psychological problems (Nevid 2013). NGO 1 line 194 also mentioned "Mandrax in the community"; NGO 2 line 194 responded "Mandrax and all that" and NGO 3 in line 221 stated that "followed by Mandrax tablets, those are your downers, weed and Mandrax". Furthermore, on the question which drugs adolescent learners use, Amanda Saunders* in Focus Group 1, line 178 responded "space muffins"; Nelisiwe Roberts* in Focus Group 1 line 254 added that "there's also nyope". In Focus Group 1, line 494, John Oliver* responded that "they use flakka" and Vernon Peters* in Focus Group 2 line 114 also stated "then you get some people that goes after this new drug, flakka". However, no supporting evidence could be located in literature regarding "Flakka".

\section{Composition of These Drugs}

\section{Marijuana}

Marijuana consists of dried leaves and flowers of the hemp plant that may be ground (Mitterer 2011; Nevid 2013, 2012). According to my findings, "space muffins" are when marijuana is added to muffin batter, particularly chocolate due to its dark colour, and baked. Verbatim responses from participants are stated below in exploring the experiences of adolescent learners regarding drug abuse in previously disadvantaged townships in South Africa. Space muffins are where "they put weed in the 
muffins while they bake it", said Nelisiwe Roberts* in Focus Group 1 line 184. "It's like a chocolate muffin where you can't see the weed in it", added Amanda Saunders* in Focus Group 1 line 202. Amanda Saunders* in Focus Group 1 line 211 explained that "most people don't like to smoke weed, they like it when it's in food".

\section{Okka Pipe}

The okka pipe was used with fruit flavours added to water as a past time for adolescent learners to smoke. Later, flavours, such as nakla and Afzal, were added to the water. I could not find any supportive evidence in literature for this finding. But, below are literal responses as derived from interviews conducted with participants in exploring peer pressure regarding drug abuse amongst adolescent learners in previously disadvantaged township secondary schools. The okka pipe is a device that adolescents use to put "water mixed with different fruit flavours" in it, as explained by NGO 1 in line 71. NGO 1 line 74 clarified that most adolescents that are booked in at the centre "use mix fruit flavours ... there's two types of flavours, nakla and Afzal ... Most of them says that Afzal is the best" (NGO 1 line 74), because "the one is light and the one is strong" (line 78).NGO 3 line 227 also reported that "they mix the flavour with the dagga and smoke it through the okka pipe". In Focus Group 1 line 222, Kevin Ockert* explainedthat "you throw all the different types of drugs in the okka pipe ... it is a mixture of all the drugs in the okka pipe".

\section{Crystal Methamphetamine}

Crystal methamphetamine, also known as crystal meth or tik, is another popular drug used by adolescent learners which consists of a pill that is melted by a candle. Sometimes the pill is crushed, lighted and smoked (Nevid 2012, 2013). Verbatim responses from participants interviewed are found below. "It's like a pill that they melt by using a candle... it's really inexpensive" (Marinda Reid, Focus Group 2 lines150-151). Zanele Shongwe in Focus Group 1 line 281 explained that "they crush it and then they light it and smoke it".

\section{Nyope}

Nyope is a dangerous drug used by adolescent learners which contains a mix of different drugs, detergents such as washing powder, other chemicals and even rat poison. Goldberg (2006) explained that, when different types of drugs are mixed, the effects are magnified due to the drug interactions. I could not find any evidence in literature that refers to nyope, however, below are exact quotes from participants interviewed. "Nyope is mixed with all kinds of drugs", said Quentin Ricketts* in Focus Group 1 line 260 who added "Nyope also contains washing powder and Rattex" in Focus Group 1 line 269. Deon Jones* in Focus Group 1 line 117 also explained that nyope is "chemicals that is combined, like all different kinds of drugs put together". 


\section{Ecstasy}

Ecstasy, on the other hand, looks and tastes like sweets, which makes it appeal to school children (Nevid 2012, 2013) or even younger as per the findings below. Ecstasy, Zanele Shongwe* in Focus Group 1 line 160 said, "is like candy, it tastes like candy ... even a five-year-old kid can use ecstasy".

\section{Flakka}

Flakka, similar to ecstasy, is a powder which also tastes like sweets. However, I could not find any evidence in literature in relation to flakka. The findings below are precise responses from participants interviewed in exploring peer pressure regarding drug abuse amongst adolescent learners in previously disadvantaged township secondary schools. "Flakka is powder and it eats like sweets", as per John Oliver* in Focus Group 1 line 500.

\section{Consumption of These Drugs}

\section{Marijuana}

Marijuana is consumed in different ways, as was discovered through the findings. These include "space muffins" that are consumed as food to prevent hunger (Maslow 1943; Nevid 2013, 2012). Marijuana is also added to the okka pipe and smoked. Below are responses as derived from interviews conducted with participants in exploring the experiences of adolescent learners regarding drug abuse in previously disadvantaged townships in South Africa. NGO 3 in line 227 stated that "there they mix the flavour with dagga and smoke it through the okka pipe". Nelisiwe Roberts* in Focus Group 1 line 202 explained that "usually when you smoke weed, you get hungry. So, when you eat it in a muffin, it makes you full, because you are eating food" and, in line 211, said: "most people don't like to smoke the weed; they like it when it's in food".

\section{Okka Pipe}

The okka pipe is a mixture of water and fruit flavours which is smoked through a device as derived from responses from participants. At a later stage, marijuana is added to the water and fruit flavours and smoked. The okka pipe appeals to both adolescent learners and older people, however, there is no evidence found in literature to support this finding. Below are responses as derived from interviews conducted with participants. NGO 1 lines 71-72described the okka pipe: "you smoke it with water and flavour ... it's the youth, but mostly the elderly people 
they are smoking it these days". NGO 3 line 227 commented that "the okka pipe, there they mix the flavour with the dagga and smoke it through the okka pipe".

\section{Crystal Methamphetamine}

Crystal methamphetamine comes in a pill (Nevid2013; 2012) that is melted with a candle crushed, lighted and smoked. The powder can also be sniffed through the nose. In support of this finding, Nevid (2013), Nevid (2012) and Mitterer (2011) concur that crystal methamphetamine can be snorted, injected or eaten. Methamphetamine is perceived as being less expensive than cocaine which is why adolescent learners prefer using crystal methamphetamine rather than cocaine. Mitterer (2011) reveals that "crystal" or "meth" can be made cheaply in backyard labs and sold at a high profit. As per interviews conducted with participants, below are literal responses from participants regarding this drug. Zanele Shongwe* in Focus Group 1 line 281 said: "they crush it, and they light it and they smoke it". They also "sniff it ... some of them move from cocaine to crystal meth, because cocaine is very expensive ... like it's not easy to get and it makes them high... meth also makes them high as cocaine, so they just switch to meth" as explained by Marinda Reid* in Focus Group 2 lines 152-154.

\section{Nyope}

Nyope can be smoked or it can be drunk as tea, as per the findings. However, no evidence of nyope could be found in literature. Below are verbatim narrations from interviews conducted with participants in exploring peer pressure regarding drug abuse amongst adolescent learners in previously disadvantaged township secondary schools. In Focus Group 1 line 258, Orifha Maluleke* explained: "you can smoke it and you can drink it as tea".

\section{Ecstasy}

Ecstasy is consumed as sweets so it appeals to school learners (Nevid 2012, 2013) or even younger children. This is corroborated in the quote below by Zanele Shongwe* in Focus Group 1 line 160 who said: "you eat it as sweets until you get high".

\section{Effects of These Drugs on Adolescent Learners}

\section{Mood Changes}

Changes in moods are evident upon using drugs. Some experience happiness (Mitterer 2011; Nevid 2012, 2013) causing them to forget about their problems (Park et al. 2007). Adolescent learners who abuse drugs use them to cope with difficult situations and deal with their feelings of failure (Lopez and Snyder 2009; Mitterer 2011; Nevid 2012; Park et al. 2007; Rathus 2012). Nevid (2013) and Nevid (2012) claim that the use of marijuana alters perceptions and causes hallucinations and that 
users feel relaxed when consuming lower dosages. On the other hand, high doses can cause nausea and vomiting, feelings of disorientation and paranoia (Nevid 2012, 2013). Anxiety and panic attacks are also evident when consuming marijuana (Nevid 2012, 2013). These theories are also corroborated below by narrations taken directly from interviews conducted with participants in exploring peer pressure regarding drug abuse amongst adolescent learners in previously disadvantaged township secondary schools. Orifha Maluleke* in Focus Group 1 lines 160-162 confessed that using drugs "brings this happiness out in you ... It made me forget about my problems ... It really makes you feel happy". Sharon Moodley* in Focus Group 1 line 164 commented that you "forget about your problems". Thus, I derived from the above comments that people want to feel happy, they do not want to think about all their problems.

\section{Personality Changes}

The findings indicated that drugs change the personalities of its users. Some changes make them unaware of what is going on around them and unable to think rationally. Consuming drugs makes users have no conscience because drug addicts do anything to get their hands on drugs, even if it means stealing from their own families. They have no sense of what is right and what is wrong, they also become aggressive, especially when they need the drugs. Adolescent learners use aggression to settle conflicts because they have not learnt alternative ways to deal with conflict (Nevid 2012, 2013). Aggression and other anti-social behaviours are interrelated (Bergin and Bergin 2012). Below are verbatim narrations as derived from interviews conducted with participants in exploring the experiences of adolescent learners regarding drug abuse in previously disadvantaged townships in South Africa. John Oliver in Focus Group 1 lines 500-502 cited that "Flakka turns you into a zombie ... you a different person when you on drugs ... You are not yourself'. NGO 1 in line 202 agreed that using drugs "changes your personality". Vernon Peters* in Focus Group 2 lines 117-118 maintained that "flakka is a dangerous drug ... flakka can cause you to go crazy". Annie Human* in Focus Group 2 lines 120-121 stated that "I think flakka is stuff that mess up your common sense ... I think it messes up the way you think". In Focus Group 2 line 126, Lorraine Simons* affirmed that "when you use drugs, you might snap mentally”. Also, in Focus Group 2 lines 129-130, Marinda Reid* added "when you use drugs, you become so used to being the bad guy that you don't have a conscience anymore ... if you do something wrong, you don't feel like you done anything wrong; you've just lost that now". NGO 1 in lines 205-210 stated that "the minute the child is doing it, the child uses substance, everything changes ... the family suffers, the traumatic drama in the house change from hundred to zero ... you come get the person used to be this person that is loving and caring and then next the person can't do anything; the person can't do it ... you can get it, that the person is influenced with substance ... everything changes ... the person starts ... getting aggressive. The person doesn't know how to behave ... the person starts getting lazy". Thus, from the reports received it was evident that the use of drugs changes the personality of its users. It is not only the user that is affected, but the experience for the family is traumatic as well. 


\section{Physical Effects}

The findings indicated that drug users consume drugs due to the physical effects that the drugs have on them; they want to get high. Some of them feel like they are walking on clouds and sometimes it makes them so high that they do not sleep for days. As per the findings, Nevid (2013), Nevid (2012) and Mitterer (2011) assert that crystal methamphetamine produces a strong high which leads to a swift habitual abuse and severe drug dependence. Rathus (2012) found that adolescent learners engage in the use of drugs because they want to escape reality and because they seek pleasure. Ecstasy causes feelings of anxiety or depression even months after a person has stopped using it (Mitterer 2011). A rise in heart rate and blood pressure, a nervous or chattering jaw and feelings of body warmth are also noticeable when using ecstasy (Nevid 2012, 2013). On the other hand, marijuana causes paranoia, hallucinations and delusions when taken in high dosages (Ksir et al. 2006; Nevid 2012, 2013). Frequent users of marijuana find it difficult to stop using it, making its dependence a risk (Budney and Hughes 2006). However, Nevid (2012, 2013), and Mitterer (2011) argue that marijuana causes psychological dependence rather than physical addiction. Nevid $(2012$, 2013) believe that drug dependence is characterised by impaired control over the use of a drug. Users feel compelled to use it or they feel powerless to stop using it even though they are aware of the dangers of the drug use (Nevid 2012, 2013). Some drugs numb the bodies, causing users to sleep for days. According to Goldberg (2006), drugs that lead to sleep, ease pain or end depression, have a high potential to be abused. Below are verbatim responses from interviews conducted with participants in exploring the experiences of adolescent learners regarding drug abuse in previously disadvantaged townships in South Africa. As evident from most of the interviews conducted, it was established that most of adolescent learners' users want to get high. Evidence of this is found in the interview conducted with NGO 2 line 192 who commented that "they chasing now the high". In Focus Group 1 line 175, Quentin Ricketts* stated that "sometimes weed makes them high". Also, in Focus Group 1 line 281, John Oliver* said that "they get high and they pass out" from the use of crystal meth. In Focus Group 2 line 108, Esther Khan* reported that "you gonna feel like you walking on clouds" and in Focus Group 2 line 151, Ingrid Meyer* confirmed that "it makes them high for like two days; you don't sleep for two days". NGO 1 lines-85 84 said: "most of them like that smoke it for the first time and affect them very badly, that's why they get like panic attacks, hallucinations ... sometimes they do it for the first time, it's a bad experience for them". NGO 1 line 187 added that "some friends they destroy someone's life, they destroy other people's life”. In Focus Group 1 line 64, Mark Gallant* mentioned that "codeine numbs the body; it makes you want to sleep"; Kevin Ockert* in Focus Group 1 line 175 added that "codeine makes them to sleep" and Deon Jones* in Focus Group 1 line 170 mentioned that "sometimes it just takes you out". 


\section{Antisocial Effects}

The findings revealed that some adolescent learners exhibit criminal behaviour to support their drug habits, sleep on the streets and may become victims of rape and murder. Anti-social behaviour includes delinquency, i.e., breaking the law, truancy, running away from home and vandalism (Bergin and Bergin 2012; Rathus 2012). Mitterer, (2011) explains that crystal methamphetamine has led to a violent criminal sub-culture. Verbatim responses from participants interviewed are found below in exploring peer pressure regarding drug abuse amongst adolescent learners in previously disadvantaged township secondary schools. In Focus Group 2 line 138, Maureen Tose* commented that "they end up not having money to buy those substances, so they end up doing burglary and robbing people to get money to buy those things". NGO 1 in line 161 said that "drugs is the first level base. Then crime comes in". In line 202 of the interview conducted with NGO 2, it was similarly noted that "it's a very big effect, because most of them they end up leaving home; they end up stealing" and NGO 2 in line 203 added: "they end up being victims of a lot of social, you know, like being raped".

\section{Academic Performance}

The findings showed that the academic performance of adolescent learners deteriorates when they abuse drugs. They have a lack of concentration; they do not pay attention in class; they cannot master the work done in class as they are not able to read and write down the work from the board. According to Cox et al. (2007), Nevid (2012, 2013) and Mitterer (2011), the academic performance of adolescent learners smoking marijuana and using crystal methamphetamine deteriorates because these drugs dampen their learning capacity and they experience learning difficulties, short-term memory loss and a lack of concentration. Below are quotations from participants interviewed. NGO 3 lines 229-231 averred that adolescent learners have a "lack of concentration, poor concentration ... You not able to grasp work in the classroom. You not able to write down the work in time from the board ... that's how you lag behind".

\section{The Stages of Drug Abuse by Adolescent Learners}

There are different stages in how drugs are introduced to adolescent learners, as indicated by the findings. Park et al. (2007) note that alcohol use often leads to cigarette smoking and this leads to the use of illicit drugs. Adolescent learners start with the okka pipe which contains fruit flavours with no drugs. Then drugs are added to the fruit flavours. From the okka pipe, adolescent learners graduate to smoking cigarettes which lead to marijuana. When the marijuana is no longer giving them that they want, they start moving towards hard-core drugs, such as crystal methamphetamine. I could not find any literature pertaining to the stages of drug abuse amongst adolescent learners to substantiate my findings but the responses from participants interviewed substantiated my findings. NGO 1 in line 59 stated: "as the child grow older, he's not only going to smoke okka pipe, but cigarettes as well". NGO 2 in 
line 192 explained that drug abuse "starts from cigarettes ... from cigarettes, it's weed, because they chasing now the high". In Focus Group 2 lines 136-137, Kaleb Thomas* elucidated that "the people that smoke drugs they start off like that, with little things such as cigarettes and weed. And they want something stronger that's gonna make them higher". Kaleb Thomas* in Focus Group 2 line 144 further explained that "you want something stronger ... The more you use it, the more it leads to overdose". NGO 2 in line 193 noted, "the weed is now no longer cool anymore";NGO 1 line 60 stated that "from the cigarettes it's going on, like in stages ... when they come to high school, they use hard-core drugs"; NGO 3 in line 24 also theorised that "usually from dagga, they go onto your more hard-core substances" and NGO 2 in line 185 maintained that "from there they graduate, and they go to tik, crystal meth, tik". NGO 2 in line 194 stressed the different stages in drug abuse reiterating "they will now go to crystal meth and then cat and Mandrax".

\section{Recommendations}

From the findings and interpretation of findings it can thus be recommended, firstly, that adolescent learners, parents and teachers to continuously attend workshops and training sessions for them to be able to assist adolescent learners to guard themselves against drug abuse. Secondly, the Department of Education and the Government to avail funds for the upgrading of the infrastructure of secondary schools in previously disadvantaged townships as well as the community to eradicate drug abuse amongst adolescent learners. Thirdly, learners found in possession of drugs must be referred for testing and counselling. If the learner is already addicted to drugs, the learner must be removed from the school and referred for rehabilitation. Fourthly, while learners are in rehabilitation, their academic work is not to be neglected. Thus, a school for drug addicted learners must be established so that these learners' academic work continues. Professionally qualified teachers must be employed at the rehabilitation school. The rehabilitation school must adhere to all the requirements of a public ordinary or private school. And lastly, I also recommend that these learners remain in rehabilitation school until they are 18 years of age. It was discovered during the interviews that, upon returning from rehabilitation, that learners relapse. This is due to them returning to the same circumstances that was the cause of their abuse of drugs.

\section{Conclusion}

The study explored the experiences of adolescent learners regarding drug abuse in previously disadvantaged townships in South Africa. It was discovered that adolescent learners get involved in the abuse of drugs due to peer influence and poor academic performance. It was also divulged that marijuana is the most commonly used drug abused by adolescent learners. Marijuana is also consumed in food, e.g. muffins containing marijuana to satisfy their hungry stomachs. These muffins are also known as "space muffins". Adolescent learners also suffer physical and psychosocial 
effects due to the abuse of drugs. It was recommended that all stakeholders stay abreast of adolescent drug use by continuously attending workshops and training sessions.

\section{Compliance with Ethical Standards}

Informed Consent Informed consent was obtained from all individual participants included in the study.

Open Access This article is licensed under a Creative Commons Attribution 4.0 International License, which permits use, sharing, adaptation, distribution and reproduction in any medium or format, as long as you give appropriate credit to the original author(s) and the source, provide a link to the Creative Commons licence, and indicate if changes were made. The images or other third party material in this article are included in the article's Creative Commons licence, unless indicated otherwise in a credit line to the material. If material is not included in the article's Creative Commons licence and your intended use is not permitted by statutory regulation or exceeds the permitted use, you will need to obtain permission directly from the copyright holder. To view a copy of this licence, visit http://creativecommons.org/licen ses/by/4.0/.

\section{References}

Adams, J., Khan, H., \& Raeside, R. (2014). Research methods for business and social science students (2nd ed.). London: Sage.

Beman, D. (1995). Risk factors leading to adolescent substance abuse. Adolescence, 30, 201-218.

Bergin, C., \& Bergin, D. (2012). Child and adolescent development in your classroom. Cengage Learning: Wadsworth.

Bernard, H., Wutich, A., \& Ryan, G. (2017). Analysing qualitative data: systematic approaches (2nd ed.). Thousand Oaks, CA: Sage.

Blakemore, S. (2008). The social brain in adolescence. Nature Reviews, Neuroscience, 9(4), 267-277.

Bogdan, R. C., \& Bilken, S. K. (1982). Qualitative research for education. An introduction to theories and models. Boston: Allyn \& Bacon Inc.

Bronfenbrenner, U. (1994). Ecological models of human development. In T. Husen \& T. N. Postlethwaite (Eds.), International encyclopedia of education (2nd ed., Vol. 3). Oxford: Elsevier.

Brown, R. E. (2001). The process of community building in distance learning classes. JALN, 5(2), 18-35.

Budney, A., \& Hughes, J. (2006). The cannabis withdrawal syndrome. Current Opinion in Psychiatry, 19(3), 233-238.

Chris Brunton and Associates. (2003). Policy handbook for educators. The Education Labour Relations Council (ELRC). Durban Universal Print Group.

Campbell, M. M.; Meades, E. E. (2007). The Viability of Corridor Development between Bloemfontein and Welkom. Retrieved from www.cib2007.com/.../CIBD2008\%20Final\%20paper\%20No\%2002. pdf. Accessed 17 Feb 2014.

Cox, R., Zhang, L., Johnson, W., \& Bender, D. (2007). Academic performance and substance use: Findings from a State Survey of Public High School Students. Journal of School Health, 77(3), 109-115.

Dahl, R. (2004). Adolescent brain development: A period of vulnerabilities and opportunities. Annals of the New York Academy of Sciences, 1021, 1-22.

Daniel, J. (2012). Sampling essentials: Practical guidelines for making sampling choices. Thousand Oaks, CA: Sage.

Dawkins, M. P. (2001). The social context of substance use among African American youth: Rural, urban and suburban comparisons. Coral Gables: Department of Sociology, University of Miami.

Denzin, N., \& Lincoln, Y. (2005). Handbook of qualitative research (3rd ed.). Thousand Oaks, CA: Sage.

Donald, D., Lazarus, S., \& Moolla, N. (2014). Educational psychology in social context (5th ed.). Oxford: Oxford University Press. 
Ellingson, L. (2009). Engaging crystallization in qualitative research: An introduction. Thousand Oaks, CA: Sage.

Elo, S., \& Kyngäs, H. (2008). Jan research methodology. The qualitative content analysis process. Journal of Advanced Nursing, 62(1), 107-115.

Erikson, E. (1968). Identity: Youth and crises. New York: Norton.

Flagel, S., Clark, J., Robinson, T., Mayo, L., Czuj, A., \& Willuhn, I. (2011). A selective role for dopamine in stimulus-reward learning. Nature, 469(7328), 53-57. https://doi.org/10.1038/nature09588.

Flick, U. (2014). The Sage handbook of qualitative data analysis. London: Sage.

Flick, U. (2015). Introducing research methodology. A beginner's guide to doing a research project. London: Sage.

Floyd, L., Alexandre, P., Hedden, S., Lawson, A., \& Latimer, W. (2010). Adolescent drug dealing and race/ethnicity: A population-based study of the differential impact of substance use on involvement in drug trade. The American Journal of Drug and Alcohol Abuse, 36, 87-91.

Gibbs, G. (2007). Analysing qualitative data. The Sage qualitative research kit. London: Sage.

Gillham, B. (2000). The research interview. Paston PrePress Ltd. Beccles, Suffolk. TJ International, Padstow, Cornwall.

Goldberg, R. (2006). Drugs across the spectrum (5th ed.). Boston, MA: Cengage Learning.

Graneheim, U. H., \& Lundman, B. (2004). Qualitative content analysis in nursing research: Concepts, procedures and measures to achieve trustworthiness. Nurse Education Today, 24, 105-112.

Groenewald, T. (2004). A phenomenological research design illustrated. Florida: Professional Educational Services, University of South Africa.

Grolier Incorporated. (1989). The new book of knowledge. Danbury, CN: Grolier Inc.

Guba, G. E., \& Lincoln, Y. S. (1988). Effective evaluation. San Francisco: Jossey-Bass.

Guest, G., Namey, E., \& Mitchell, M. (2013). Collecting qualitative date: A field manual for applied research. London: Sage.

Harber, C. (2001). Schooling and violence in South Africa: Creating a safer school. Intercultural Education, 12, 261-271.

Harding, J. (2013). Qualitative data analysis from start to finish. London: Sage.

Hartney, E. (2014). What is peer pressure? Retrieved from https://addictions.about.com/od/howaddicti onhappens/f/Peer_Pressure.html. Accessed 05 April, 2015.

Henning, E., Van Rensburg, W., \& Smit, B. (2004). Finding your way in qualitative research. Pretoria: Van Schaik.

Hesse-Biber, S., \& Leavy, P. (2011). The practice of qualitative research (2nd ed.). London: Sage.

Husserl, E. (1907). The idea of phenomenology, W.P. Alston and G. Nakhnikian, trans. The Hague: Nijhoff.

Joffe, V., \& Black, E. (2012). Social, emotional and behavioural functioning of secondary school students with low academic and language performance: Perspectives from students, teachers and parents. American Speech-Language-Hearing Association, 43, 461-473.

Khanzode, V. (2011). Research methodology: Techniques and trends. New Delhi: S.B. Nangia. A P H Publishing Corporation.

Kothari, C. \& Garg, G. (2014). Research methodology: Methods and techniques, 3rd edition. New Delhi: New Age International (P) Ltd.

Kumar, R. (2014). Research methodology: A step-by-step guide for beginners (4th ed.). London: Sage.

Ksir, C., Hart, C., \& Ray, O. (2006). Drugs, society and human behaviour (11th ed.). New York: McGraw-Hill.

Kvale, S. (2007). Doing interviews. The Sage qualitative research kit. London: Sage.

Leedy, P. D. (1997). Practical research: Planning and design (6th ed.). Upper Saddle River, NJ: Prentice Hall Inc.

Leedy, P., \& Ormrod, J. (2014). Practical research. planning and design (10th ed.). Harlowe, Essex: Pearson Education Limited.

Leggett, T. (2004). Still marginal. Crime in the coloured community. Crime Quarterly. https://doi. org/10.17159/2413-3108/2004/v0i7a1047.

Lester, S. (1999). An introduction to phenomenological research. Taunton: Stan Lester Developments.

Lopez, S., \& Snyder, C. (2009). Oxford handbook of positive psychology (2nd ed.). Oxford: Oxford University Press.

Marshall, C., \& Rossman, D. (2006). Designing qualitative research. Thousand Oaks. London: Sage.

Maslow, A. (1943). A theory of human motivation. Psychological Review, 50, 370-396. 
Maxwell, J. A. (2008). Designing a qualitative study. Qualitative Research. https://doi.org/10.4135/97814 83348858 n7.

Merriam, S. B. (1998). Qualitative research and case study applications in education. Revised and expanded from the case study research in education. San Francisco: Jossey-Bass.

Mill, J. S. (1898). A system of logic, ratiocinative and inductive: Being a connected view of the principles of evidence and the methods of scientific investigation. People's ed. London: Longmans, Green and Co.

Mitterer, C. (2011). Psychology: A journey (Int ed.). Boston, MA: Cengage Learning.

Morse, J. M. (1994). Critical issues in qualitative research methods. London, New Delhi: International Educational and Professional Publisher Sage.

Motseke, M. (2013). Perceived learner school citizenship behaviours in a sample of historically disadvantaged South African schools. Journal of Psychology in Africa, 23(1), 129-132.

Nevid, J. (2012). Essentials of psychology: Concepts and applications (3rd ed.). Boston, MA: Cengage Learning.

Nevid, J. (2013). An introduction to psychology (4th ed.). Boston, MA: Cengage Learning.

Ngonini, X. A. (2007). Anxious communities: The decline of the mine migration in the Eastern Cape. Development Southern Africa, 24(1), 173-185.

O'Reilly, M., \& Kiyimba, N. (2015). Advanced qualitative research: A guide to using theory. London: Sage.

Oxford South African Concise Dictionary. (2011). The dictionary unit for South African English (2nd ed.). Oxford: Oxford University Press.

Pandit, N. R. (1996). The creation of theory: A recent application of the grounded theory method. The Qualitative Report, 2(4), 1-15.

Park, S., Kim, H. S., Kim, H., \& Sung, K. (2007). Exploration of the prevalence and correlates of substance use among sheltered adolescents in South Korea. Adolescence, 42(167), 603-616.

Parry, C., Myers, B., Morojele, N., Flisher, A., Bhana, A., \& Donson, H. (2004). Trends in adolescent alcohol and other drug use: Findings from three sentinel sites in South Africa (1997-2001). Journal of Adolescence, 27(4), 429-440.

Pastorino, E., \& Doyle-Portillo, S. (2009). What is psychology? (2nd ed.). Belmont, CA: Wadsworth.

Pelser, E. (2008). Learning to be lost: Youth crime in South Africa. Discussion Paper for the HSRC Youth Policy Initiative, Reserve Bank, Pretoria. Centre for Justice and Crime Prevention.

Ponterotto, J. (2005). Qualitative research in counselling psychology: A primer on research paradigms and the philosophy of science. Journal of Counselling Psychology, 52(2), 126-136.

Rathus, S. (2012). Psychology: Concepts and connections (10th ed.). Boston, MA: Cengage Learning.

Remler, D., \& Van Ryzin, G. (2011). Research methods in practice. Strategies for description and causation. London: Sage.

Richards, L., \& Morse, J. (2013). Readme first for a user's guide to qualitative methods (3rd ed.). London: Sage.

Ritchie, J., \& Lewis, J. (2003). Qualitative research practice: A guide for social science students and researchers. Thousand Oaks, CA: Sage.

Rubin, H., \& Rubin, I. (2005). Qualitative interviewing: The art of hearing data (2nd ed.). London: Sage.

Scott, G., \& Garner, R. (2013). Doing qualitative research: Designs, methods and techniques (1st ed.). London: Pearson Education Inc.

South African Council for Educators (SACE). (2011). An overview of school-based violence in South Africa. School-based violence report. Centurion, South Africa.

Spear, L. (2000). The adolescent brain and age-related behavioural manifestations. Neuroscience and Behavioural Reviews, 24, 417-463.

Strauss, A., \& Corbin, J. (1999). Basics of qualitative research. Techniques and procedures for developing grounded theory (2nd ed.). Newbury Park: Sage.

Van Niekerk, T., \& Wolvaardt, J. (2011). Oxford South African concise dictionary (2nd ed.). Oxford: Oxford University Press.

Van Zyl, P. (2019). Underwriting and claims conference, 3-5 February 2019. The human interface. Legislation of Cannabis.

Webster-Stratton, C., \& Taylor, T. (2001). Nipping early risk factors in the bud: Preventing substance abuse, delinquency and violence in adolescence through interventions targeted at young children (0-8 Years). Prevention Science, 2(3), 165-192. 
Wechsberg, W. M., Jones, H. E., Zule, W. A., Myers, B. J., Browne, F. A., Kaufman, M. R., et al. (2010). Methamphetamine ("tik") use and its association with condom use among out-of-school females in Cape Town, South Africa. The American Journal of Drug and Alcohol Abuse, 36, 208-213.

Welman, J. C., \& Kruger, S. J. (1999). Research methodology for the business and administrative sciences. Johannesburg: Thompson International.

Wickham, S. (2000). The educator as a researcher. Guidelines for educators undertaking action research.

Publisher's Note Springer Nature remains neutral with regard to jurisdictional claims in published maps and institutional affiliations. 